\title{
Isolated Pd Sites as Selective Catalysts for Electrochemical and Direct Hydrogen Peroxide Synthesis
}

\author{
Marc Ledendecker, Enrico Pizzutilo, Grazia Malta, Guilherme V. Fortunato, Karl J. J. Mayrhofer, \\ Graham J. Hutchings, and Simon J. Freakley*
}

Cite This: ACS Catal. 2020, 10, 5928-5938

Read Online

\section{ACCESS | Llll Metrics \& More | 国 Article Recommendations | (s) Supporting Information}

ABSTRACT: Palladium nanoparticles have been studied extensively as catalysts for the direct synthesis of hydrogen peroxide, where selectivity remains a key challenge. Alloying Pd with other metals and using acid and halide promoters are commonly employed to increase $\mathrm{H}_{2} \mathrm{O}_{2}$ selectivity; however, the sites that can selectively produce $\mathrm{H}_{2} \mathrm{O}_{2}$ have not been identified and the role of these additives remains unclear. Here, we report the synthesis of atomically dispersed $\mathrm{PdCl}_{x} / \mathrm{C}$ as a model catalyst for $\mathrm{H}_{2} \mathrm{O}_{2}$ production without the presence of extended Pd surfaces. We show that these isolated cationic Pd sites can form $\mathrm{H}_{2} \mathrm{O}_{2}$ with significantly higher selectivity than metallic Pd nanoparticles in both the reaction of $\mathrm{H}_{2}$ and $\mathrm{O}_{2}$ and the electrochemical oxygen reduction reaction. These results demonstrate that catalysts containing high populations of isolated $\mathrm{Pd}$ sites are selective catalysts for this two-

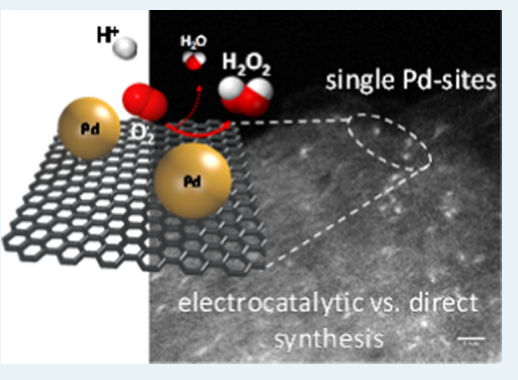
electron reduction reaction and that the performance of materials in the direct synthesis reaction and electrocatalytic oxygen reduction reaction has many similarities.

KEYWORDS: catalysis, hydrogen peroxide, palladium, electrocatalysis

\section{INTRODUCTION}

Hydrogen peroxide $\left(\mathrm{H}_{2} \mathrm{O}_{2}\right)$ is an increasingly important commodity chemical due to its high oxidation potential and low environmental impact with water being the only byproduct of its many applications. ${ }^{1} \mathrm{H}_{2} \mathrm{O}_{2}$ is currently used extensively in the pulp and paper industry and increasingly in selective oxidation processes on a large scale; such as the hydrogen peroxide propylene oxide (HPPO) process. ${ }^{2}$ In addition, $\mathrm{H}_{2} \mathrm{O}_{2}$ is considered a key component in future water purification technology in remote areas. ${ }^{3}$ Currently, the vast majority of $\mathrm{H}_{2} \mathrm{O}_{2}$ is produced through the indirect anthraquinone process via the sequential reduction and oxidation of a substituted anthraquinone in an organic working solution. ${ }^{4}$ While highly optimized and able to produce large quantities of concentrated $\mathrm{H}_{2} \mathrm{O}_{2}$, new approaches are being continually sought to allow decentralized continuous production of $\mathrm{H}_{2} \mathrm{O}_{2}$ at the point of use without the need for storage and transport. ${ }^{5,6}$

The selective catalytic production of $\mathrm{H}_{2} \mathrm{O}_{2}$ from molecular hydrogen $\left(\mathrm{H}_{2}\right)$ and oxygen $\left(\mathrm{O}_{2}\right)$ has been a target for Pd heterogeneous catalysts since the first patents appeared in 1914..$^{7}$ Numerous Pd nanoparticle-based catalysts have been extensively studied as promising candidates for this challenging hydrogenation, although systems with satisfactorily high selectivity and rate are limited. The problems of overhydrogenation and decomposition of $\mathrm{H}_{2} \mathrm{O}_{2}$ to produce $\mathrm{H}_{2} \mathrm{O}$ limit the application of monometallic Pd catalysts without the addition of additives to the reaction or alloying with secondary metals to form bimetallic catalysts. These systems have recently been extensively reviewed by numerous groups, highlighting the potential of this process. $^{8-14}$ Typically, acid and halide additives are used to stabilize the synthesized $\mathrm{H}_{2} \mathrm{O}_{2}$ and increase selectivity based on $\mathrm{H}_{2}$. It is postulated that halide additives can selectivity block high activity $\mathrm{Pd}$ sites on nanoparticles, reducing the overhydrogenation rates. ${ }^{15-17}$ Alternatively, bimetallic particles including noble metals such as $\mathrm{Au}^{18-20}$ and base metals such as $\mathrm{Sn}^{21} \mathrm{Ni}^{22}$ and $\mathrm{Zn}^{23,24}$ have been shown to be able to produce $\mathrm{H}_{2} \mathrm{O}_{2}$ with high efficiency and in some cases with a $\mathrm{H}_{2}$ selectivity of more than $95 \%$ in the absence of acids and halides. This demonstrates that the sites for $\mathrm{H}_{2} \mathrm{O}_{2}$ synthesis and $\mathrm{H}_{2} \mathrm{O}_{2}$ degradation are different and can be isolated. ${ }^{20,21}$

Recently, based on a comprehensive kinetic analysis to determine the effects of $\mathrm{H}_{2}$ and $\mathrm{O}_{2}$ partial pressure, temperature, and $\mathrm{pH}$ (including the use of protic and aprotic solvents), it was proposed that the mechanism of $\mathrm{H}_{2} \mathrm{O}_{2}$ formation on $\mathrm{Pd}$ involves sequential electron-proton transfer to surface-bound $\mathrm{O}_{2}$ and $\mathrm{OOH}$ species rather than a purely Langmuir-type surface model. ${ }^{25}$ This mechanism implies that two half-reactions are occurring at the metal nanoparticle; hydrogen oxidation to protons to supply electrons for oxygen reduction by proton-coupled electron transfer, rationalizing the

Received: March 20, 2020

Revised: April 21, 2020

Published: April 23, 2020 

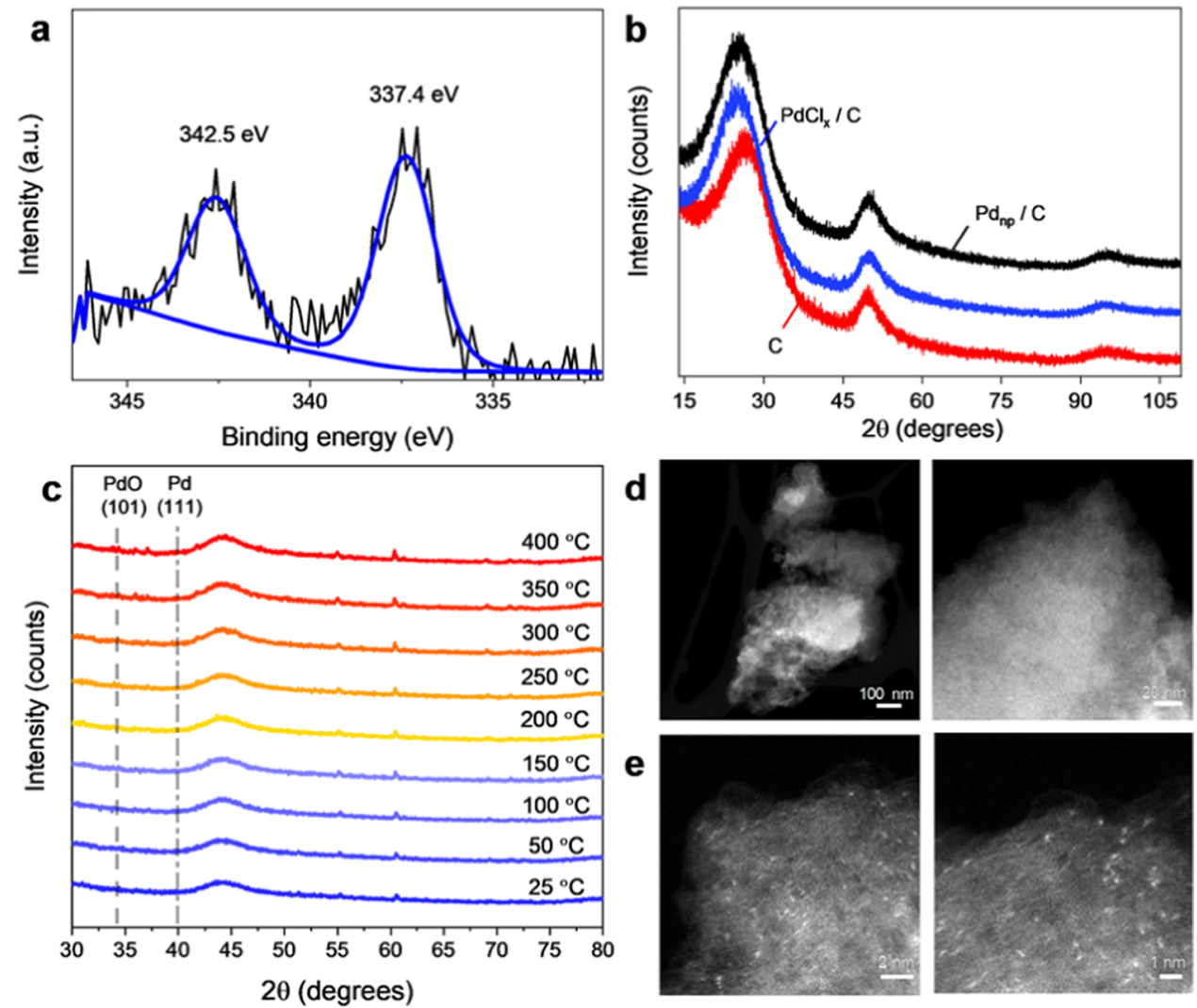

Figure 1. Characterization of the as-prepared $1 \% \mathrm{PdCl}_{x} / \mathrm{C}$ catalyst by (a) $\mathrm{Pd} 3 \mathrm{~d}_{5 / 2} \mathrm{X}$-ray photoelectron spectroscopy and (b) X-ray diffraction (XRD). Bare carbon and $\mathrm{Pd}_{\mathrm{np}} / \mathrm{C}$ are shown for comparison. (c) In situ X-ray diffraction at increasing temperatures under a flow of Ar. (d) Representative transmission electron microscopy (TEM) images and (e) high-angle annular dark-field scanning transmission electron microscopy (HAADF-STEM) images.

observed dependence on the $\mathrm{pH}$ and the need for protic solvents. This also dictates that when using a nonconducting catalyst support, such as $\mathrm{TiO}_{2}$ and $\mathrm{SiO}_{2}$, both reactions must occur simultaneously on the same nanoparticle. These two half-reactions, akin to a fuel cell, rely on the chemical potential of $\mathrm{H}_{2}$ as the driving force for the reaction and are analogous to applying an electrical potential to drive the oxygen reduction reaction (ORR) electrochemically. This suggests that materials that are selective toward the two-electron oxygen reduction in the reaction of $\mathrm{H}_{2}$ and $\mathrm{O}_{2}$ will be selective in electrochemical ORR if they are conductive and vice versa; selective ORR catalysts should perform well in the direct synthesis reaction if they are able to activate $\mathrm{H}_{2}$.

While $\mathrm{Pd}$ and $\mathrm{Pt}$ typically catalyze the four-electron reduction of $\mathrm{O}_{2}$ to $\mathrm{H}_{2} \mathrm{O}$, a number of materials have been identified as potential catalysts for the two-electron reduction of $\mathrm{O}_{2}$ to $\mathrm{H}_{2} \mathrm{O}_{2}$, with an overview given recently by Stephens and co-workers. ${ }^{26-29}$ Bare carbon-based materials have been shown to achieve high selectivity in the half-cell ORR to form $\mathrm{H}_{2} \mathrm{O}_{2}$; however, the reaction rates for the HOR are usually low, severely limiting the activity for the direct synthesis reaction in the absence of precious metals. ${ }^{30}$ In contrast, extended $\mathrm{Pd} / \mathrm{Pt}$ surfaces are highly active toward the HOR and the reduction of $\mathrm{O}_{2}$, often resulting in $\mathrm{O}-\mathrm{O}$ bond rupture and therefore low selectivity. $^{31}$

One approach to achieve high selectivity is partial surface blocking with amorphous carbon layers, allowing the diffusion of reactants to the surface while promoting end-on rather than side-on binding of $\mathrm{O}_{2}$-suppressing $\mathrm{H}_{2} \mathrm{O}$ formation and reaching a $\mathrm{H}_{2} \mathrm{O}_{2}$ selectivity of $30 \%$ at $0.3 \mathrm{~V}$ using Pt catalysts. ${ }^{32}$ Numerous studies have focused on alloying two metals to achieve synergistic effects between metals that bind $\mathrm{O}_{2}$ strongly such as $\mathrm{Pt}$ and $\mathrm{Pd}$ and a second metal that binds $\mathrm{O}_{2}$ weakly such as $\mathrm{Au}$ and $\mathrm{Hg} .{ }^{33-35}$ These studies typically report improved selectivity toward $\mathrm{H}_{2} \mathrm{O}_{2}$ compared to the monometallic Pd or Pt catalysts through both site isolation and electronic effects. A key example of this approach is a $\mathrm{PdHg} / \mathrm{C}$ catalyst, which can achieve a selectivity of around $90 \%$ toward $\mathrm{H}_{2} \mathrm{O}_{2}$ at $0.3-0.5 \mathrm{~V}$ and has been shown to consist of nanoparticles containing a metallic $\mathrm{Pd}$ core and a $\mathrm{PdHg}$ alloy outer shell. $^{36,37}$ In addition to challenges around mercury toxicity, to the best of our knowledge, no examples of $\mathrm{Hg}$ based hydrogenation catalysts have been reported, suggesting that the direct production of $\mathrm{H}_{2} \mathrm{O}_{2}$ on bare $\mathrm{Hg}$ will be limited as the rate of $\mathrm{H}_{2}$ activation will be low. As overpotentials higher than $1 \mathrm{~V}$ at $25{ }^{\circ} \mathrm{C}$ were reported to be required to catalyze the hydrogen evolution reaction, similar overpotentials for the HOR can be expected. ${ }^{38}$ At the limits of site isolation, isolated $\mathrm{Pt}$ species have recently been stabilized on $\mathrm{TiC}^{39}$ and $\mathrm{TiN}^{40}$ supports with a potential-dependent $\mathrm{H}_{2} \mathrm{O}_{2}$ selectivity between 60 and $80 \%$. High-sulfur-containing (17 wt \%) carbonaceous materials have been shown to support high dispersion of $\mathrm{Pt}$ and demonstrate high selectivity (95\% at 0.71 $\mathrm{V}$ onset potential) toward $\mathrm{H}_{2} \mathrm{O}_{2}$ in the ORR in addition to Coporphyrin containing catalysts that were able to achieve $90 \%$ selectivity (at $-0.1 \mathrm{~V}$ ) with an onset potential of approx. $0.5 \mathrm{~V}$ in an rotating ring disc electrode (RRDE) setup. ${ }^{41,42}$ 

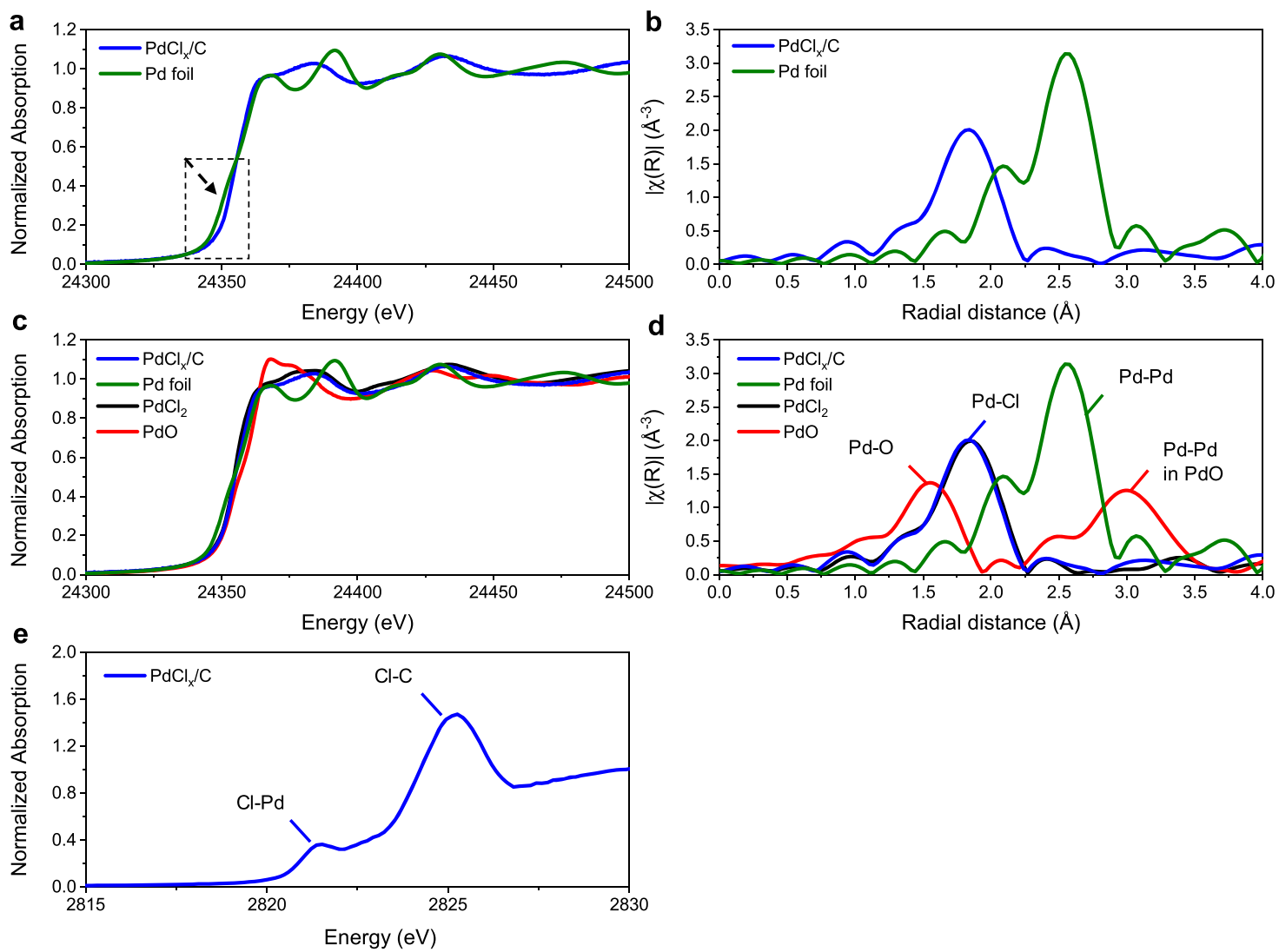

Figure 2. $(\mathrm{a}-\mathrm{d}) \mathrm{Pd}$ K-edge X-ray absorption spectra and $k^{3}$-weighted Fourier transform (FT) magnitude of the as-prepared $\mathrm{PdCl} \mathrm{Cl}_{x} / \mathrm{C}$ and $\mathrm{Pd}$ standards ( $\mathrm{Pd}$ foil, $\mathrm{PdO}, \mathrm{PdCl}_{2}$ ). (e) $\mathrm{Cl} \mathrm{K-edge} \mathrm{X-ray} \mathrm{absorption} \mathrm{spectra} \mathrm{of} \mathrm{the} \mathrm{fresh} \mathrm{PdCl}_{x} / \mathrm{C}$ catalyst material.

In this study, we report the synthesis of an atomically dispersed carbon-supported Pd catalyst and show that this material is active and highly selective in the electrochemical $\mathrm{ORR} / \mathrm{HOR}$ and the direct synthesis reaction to produce $\mathrm{H}_{2} \mathrm{O}_{2}$ from molecular $\mathrm{H}_{2}$ and $\mathrm{O}_{2}$. Through electrochemical half-cell testing, the HOR and ORR can be investigated independently and conclusions for the direct synthesis can be drawn. The material shows that the continuous production of $\mathrm{H}_{2} \mathrm{O}_{2}$ is possible with high atom efficiency using precious metal catalysts without the need to design bimetallic alloys or selectively block nanoparticle surface sites.

\section{RESULTS AND DISCUSSION}

Studies by Schiffrin and Jirkovský have shown that low levels of Pd in Au-rich AuPd bimetallic nanoparticles could act as reactive "hotspots" with increased two-electron ORR selectivity, in agreement with our observations that as Pd selectively leaches from AuPd nanoparticles two-electron ORR selectivity increases. $^{33,43,44}$ This led us, in combination with the recent kinetic studies on direct $\mathrm{H}_{2} \mathrm{O}_{2}$ synthesis from $\mathrm{H}_{2}$ and $\mathrm{O}_{2}$, to hypothesize that isolated $\mathrm{Pd}$ sites supported on conductive materials could act as selective catalysts for both the electrochemical ORR and the direct synthesis of $\mathrm{H}_{2} \mathrm{O}_{2}$ from $\mathrm{H}_{2} / \mathrm{O}_{2}$ mixtures via the type of coupled proton-electron mechanism recently proposed. ${ }^{25}$ We recently reported the synthesis and characterization of an atomically dispersed $1 \%$ $\mathrm{Au} / \mathrm{C}$ catalyst that was shown to be stable at high temperatures. ${ }^{45}$ This catalyst was prepared by the deposition of $\mathrm{Au}$ onto activated carbon from an aqua regia solvent before drying at $140{ }^{\circ} \mathrm{C}$. We extended this approach to the synthesis of $1 \% \mathrm{Pd} / \mathrm{C}$ using a $\mathrm{PdCl}_{2}$ precursor and Norit ROX 0.8 carbon support by incipient wetness; the catalyst material was prepared on a $2 \mathrm{~g}$ scale.

The initial characterization of the catalyst material by X-ray photoelectron spectroscopy (XPS) to confirm the presence and oxidation state of $\mathrm{Pd}$ is shown in Figure 1a. The spectra of the $\mathrm{Pd} 3 \mathrm{~d}$ region shows the expected splitting and binding energy of oxidized Pd species (Pd(II) $3 \mathrm{~d}_{5 / 2}, 337.4 \mathrm{eV}$ ) with no presence of secondary metallic Pd speciation $\left(\mathrm{Pd} 3 \mathrm{~d}_{5 / 2}, 335.0\right.$ $\mathrm{eV}) .{ }^{46}$ This is consistent with the highly oxidizing nature of the impregnation solvent followed by heat treatment under an inert atmosphere and confirms the deposition of the $\mathrm{Pd}$ precursor on the carbon surface. Table S1 reports the surface composition of the as-prepared catalyst and confirms a $\mathrm{Pd}$ loading of 0.16 atom $\%$ corresponding to $1.3 \mathrm{wt} \%$, in addition to significant $\mathrm{Cl}(6.7 \mathrm{wt} \%)$ and $\mathrm{O}(8.1 \mathrm{wt} \%)$ content on the carbon surface. Chlorine (1s) binding energies (Figure S1) are suggestive of the presence of both inorganic and organic $\mathrm{Cl}$ species on the catalyst surface. However, organic $\mathrm{Cl}$ dominates the signal with binding energies of $\sim 200 \mathrm{eV}$, suggesting the formation of $\mathrm{C}-\mathrm{Cl}$ surface groups.

$\mathrm{X}$-ray diffraction (XRD) analysis of the freshly prepared $1 \%$ $\mathrm{Pd} / \mathrm{C}$ (Co $\mathrm{K}_{\alpha}$ radiation source) to exclude the formation of crystalline $\mathrm{PdO} / \mathrm{Pd}$ (Figure $1 \mathrm{~b}$ ) revealed the absence of the principle reflections of either nanocrystalline metallic $\operatorname{Pd}(111)$ at $45^{\circ}$ (JCPDS no. 46-1043) or $\mathrm{PdO}(101)$ at $40^{\circ}$ (JCPDS no. 41-1107), indicating either the metal crystallite size or the metal loading of the catalyst is below the limits of detection. For comparison, $1 \% \mathrm{Pd} / \mathrm{C}$ prepared by sol immobilization containing metallic $\mathrm{Pd}$ nanoparticles with an average size of 4.3 $\pm 1.0 \mathrm{~nm}$, determined by TEM (Figure S2) and denoted as 

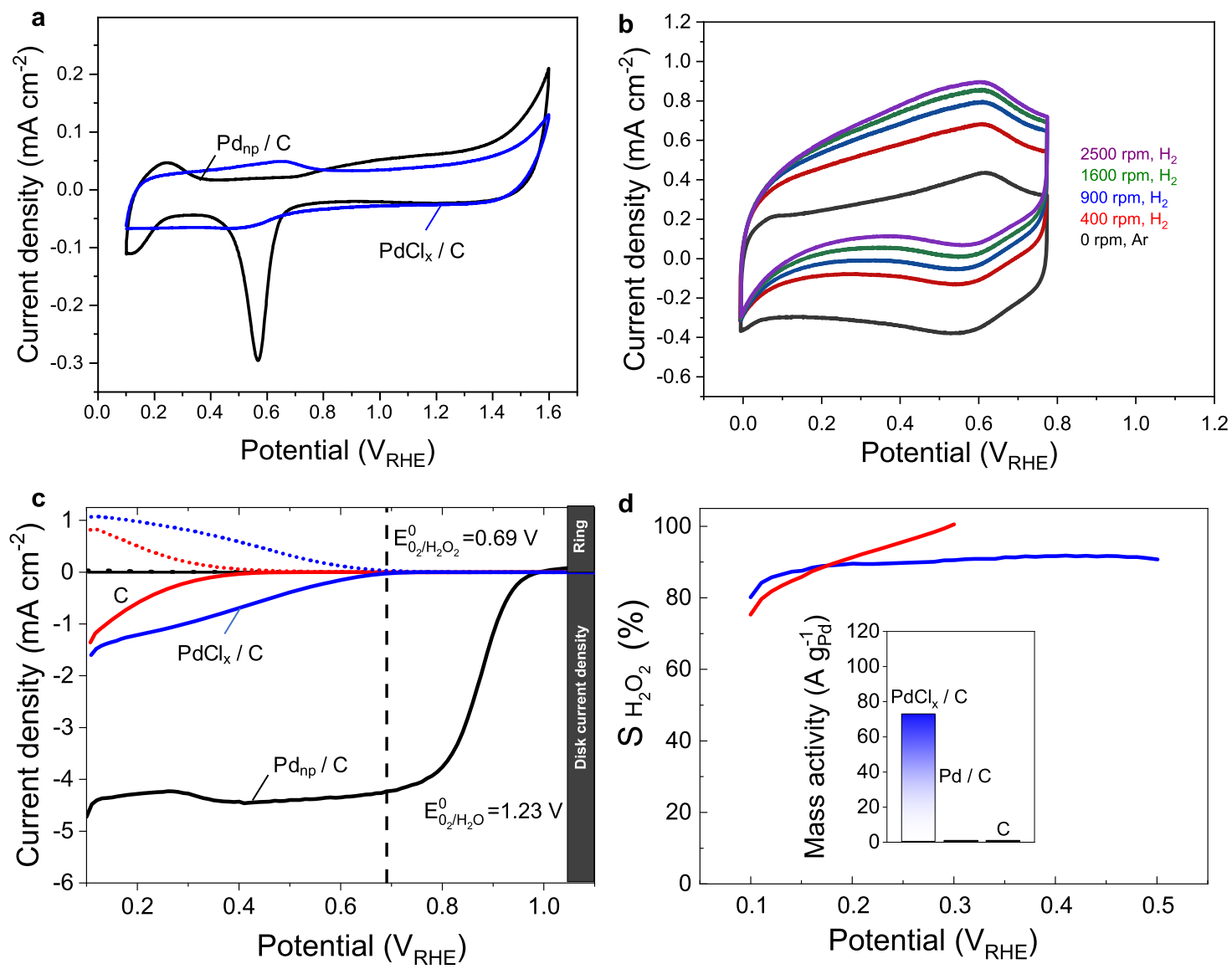

Figure 3. (a) Cyclic voltammogram at $50 \mathrm{mV} \mathrm{s}^{-1}$ between 0.1 and $1.6 \mathrm{~V}_{\mathrm{RHE}}$ in $\mathrm{Ar}$-saturated $0.1 \mathrm{M} \mathrm{HClO}_{4}$ of $\mathrm{PdCl}_{x} / \mathrm{C}$ and $\mathrm{Pd}$ np $/ \mathrm{C}$. (b) Cyclic voltammogram of $\mathrm{PdCl}_{x} / \mathrm{C}$ at $50 \mathrm{mV} \mathrm{s}^{-1}$ at different rotation speeds $(0,400,900,1600,2500 \mathrm{rpm})$ in hydrogen-saturated $\mathrm{HClO}_{4}$ between -0.005 and $0.775 \mathrm{~V}_{\mathrm{RHE}}$ (c) $\mathrm{RRDE}$ results for $\mathrm{PdCl}_{x} / \mathrm{C}, \mathrm{Pd}_{\mathrm{np}} / \mathrm{C}$ and $\mathrm{C}$ in $\mathrm{O}_{2}$-saturated $0.1 \mathrm{M} \mathrm{HClO}_{4}$ at $50 \mathrm{mV} \mathrm{s}^{-1}, 900$ rpm, and potential scan from 0.1 to $1.2 \mathrm{~V}$ and the (d) corresponding potential-dependent selectivities $S_{\mathrm{H}_{2} \mathrm{O}_{2}}$.

$\left(\mathrm{Pd}_{\mathrm{np}} / \mathrm{C}\right)$, is also included in addition to the bare carbon support, which both also show the absence of diffraction peaks.

We performed in situ XRD $\left(\mathrm{Cu} \mathrm{K} \mathrm{K}_{\alpha}\right.$ radiation source) of the fresh catalyst material at increasing temperatures under an $\mathrm{Ar}$ atmosphere to determine whether the possible high dispersion of $\mathrm{Pd}$ was susceptible to thermally induced sintering/ decomposition. Figure 1c shows that the absence of diffraction patterns is maintained at $400{ }^{\circ} \mathrm{C}$, suggesting that the possible high dispersion of $\mathrm{Pd}$ species remains strongly anchored to the support material. Transmission electron microscopy (TEM) imaging of the fresh sample at low and medium magnifications (Figure 1d) revealed the absence of Pd nanoparticles in the nanometer size range on the carbon support material, consistent with the XRD observations. High-angle annular dark-field scanning transmission electron microscopy (HAADF-STEM) (Figure 1e) revealed the presence of a population of $\mathrm{Pd}$ species significantly smaller than $1 \mathrm{~nm}$ appearing in near-atomic dispersion with the absence of any $\mathrm{Pd}$ nanoparticle structures. This suggests that the $\mathrm{PdCl}_{x} / \mathrm{C}$ catalyst material does not contain extended Pd surfaces or small metallic Pd nanoparticles, which has been suggested to lead to low $\mathrm{H}_{2} \mathrm{O}_{2}$ selectivity in the direct synthesis or ORR reactions through the promotion of overhydrogenation.

X-ray absorption spectroscopy (XAS) of the highly dispersed catalyst (Figure 2a) at the Pd K-edge supported the observations of the XPS measurements that Pd is in a cationic state (edge position, $24354 \mathrm{eV}$ ), consistent with the existing literature and clearly higher than the absorption edge of a metallic Pd foil (edge position, $24350 \mathrm{eV}$ ) recorded during the same experiment. In addition, significantly different post-edge structures were observed, suggesting that $\mathrm{Pd}$ is not present as metallic nanoparticles below the diffraction limit. ${ }^{47}$ Extended X-ray absorption fine structure (EXAFS) nonphase-corrected analysis (Figure 2b) further corroborates the absence of higher-nuclearity Pd structures. In comparison to the metallic Pd foil, the synthesized catalyst shows no features in the Fourier transform (FT) consistent with the recorded standards and literature examples of scattering intensity resulting from $\mathrm{Pd}-\mathrm{Pd}$ scattering paths in metallic Pd structures. ${ }^{47}$ When compared to those of the other cationic Pd standards (Figure $2 \mathrm{c}, \mathrm{d})$, the recorded spectra of the catalyst better match the reference $\mathrm{PdCl}_{2}$ spectra, suggesting that the shortest scattering event is not consistent with the $\mathrm{Pd}-\mathrm{Pd}$ or $\mathrm{Pd}-\mathrm{O}$ scattering of metallic $\mathrm{Pd}$ or $\mathrm{PdO}$ but with the $\mathrm{Pd}-\mathrm{Cl}$ scattering path (Pd$\mathrm{Cl}$ coordination number, $3.99 \pm 0.4$; fitting parameters are shown in Figure S3). Additional low-energy XAS at the Cl Kedge shown in Figure 2e revealed the presence of two distinct $\mathrm{Cl}$ features, consistent with $\mathrm{C}-\mathrm{Cl}$ and $\mathrm{Pd}-\mathrm{Cl}$ type chlorine environments in the catalyst material, suggesting highly dispersed cationic $\mathrm{Pd}$ species with a $\mathrm{Cl}$ ligand environment (denoted $\mathrm{PdCl}_{x} / \mathrm{C}$ subsequently). ${ }^{48,49} \mathrm{~A}$ comparison of the EXAFS model of the first coordination shell of the $\mathrm{PdCl}_{2}$ standard with our catalyst material reveals no significant shift in the position of the scattering event on forming the dried 
catalyst material. This indicates that there are limited additional scattering paths, such as $\mathrm{Pd}-\mathrm{O}$ or $\mathrm{Pd}-\mathrm{N}$, between the Pd and catalyst surface in the material. These bond lengths would be considerably shorter than the $\mathrm{Pd}-\mathrm{Cl}$ bond lengthfor example, $\mathrm{Pd}-\mathrm{O}$ based on $\mathrm{Pd}$ acetate as a model of $\mathrm{Pd}-\mathrm{O}-$ $\mathrm{C}$ would be approximately $0.3 \AA$ shorter than the observed intensity, consistent with $\mathrm{Pd}-\mathrm{Cl}^{50}$ As we see no change in $\mathrm{Pd}-\mathrm{Cl}$ coordination or agglomerates in the STEM analysis, we suggest that $\mathrm{PdCl}_{4}{ }^{2-}$ is adsorbed on the carbon surface mainly through electrostatic interactions rather than ligand exchange with oxygen-containing groups on the carbon surface. Another possibility is that chorine on the surface of carbon, as a result of the aqua regia treatment, could be the anchor point between the carbon and $\mathrm{Pd}$ species, providing bridging $\mathrm{Cl}$ species similar to the bulk structure of $\mathrm{PdCl}_{2}$.

Recently, it has been suggested that the mechanism of direct synthesis of $\mathrm{H}_{2} \mathrm{O}_{2}$ from $\mathrm{H}_{2}$ and $\mathrm{O}_{2}$ could follow an electrochemical-type ORR mechanism initiated by the oxidation of $\mathrm{H}_{2}$ into protons with coupled electron transfer to adsorbed $\mathrm{O}_{2}$ or $\mathrm{OOH}$ species on the same particle. ${ }^{25}$ In this case, good correlations could be made by studying the electrochemical ORR and direct synthesis using the same materials. In our previous studies using AuPd nanoparticles with varying $\mathrm{Au} / \mathrm{Pd}$ ratios, these correlations can be seen between catalyst activity and selectivity at certain electrochemical potentials_-presumably, these potentials correspond to the chemical potential of the heterogeneous reactor system under our chosen reaction conditions. ${ }^{33,35,51,52}$ Using the synthesized single-site Pd catalyst, the activity in the direct synthesis reaction could be expected to be greatly reduced if adjacent $\mathrm{Pd}$ sites are required for $\mathrm{H}_{2}$ activation. A study by Han et al. recently reported that single Pd sites supported on hydroxyapatite $\left(\mathrm{CaPO}_{4}\right)$ showed limited activity for $\mathrm{H}_{2} \mathrm{O}_{2}$ synthesis and low-nuclearity Pd clusters were required for $\mathrm{H}_{2}$ activation, ${ }^{53}$ although a single-site Pd-carbon nitride material has been shown to be active for alkene/alkyene hydrogenation previously. ${ }^{54}$ In contrast during electrochemical ORR in acidic media, the $\mathrm{H}^{+} / \mathrm{e}^{-}$couple is supplied to the catalyst surface without the need for $\mathrm{H}_{2}$ activation, removing the requirement for $\mathrm{H}_{2}$ activation to produce $\mathrm{H}_{2} \mathrm{O}_{2}$.

To compare the surface structure and the potentialdependent surface coverage of adsorbing species, cyclic voltammetry $(\mathrm{CV})$ of the atomically dispersed $1 \% \mathrm{PdCl}_{x} / \mathrm{C}$ catalyst was conducted and the voltammograms were compared to those of the $1 \% \mathrm{Pd} / \mathrm{C}$ catalyst prepared by our previously reported sol immobilization methods to generate metallic Pd nanoparticles with a 2-6 nm size distribution (Figure S2) (denoted 1\% $\mathrm{Pd}_{\mathrm{np}} / \mathrm{C}$ ) (Figure 3a). ${ }^{51,52}$ Inspection of the voltammograms between 0.1 and $1.6 \mathrm{~V}_{\mathrm{RHE}}$ revealed markedly different redox characteristics, especially in the region of hydrogen underpotential deposition $\left(\mathrm{H}_{\mathrm{UPD}}, \mathrm{H}^{+}+\right.$ $\mathrm{e}^{-} \rightarrow \mathrm{H}_{\text {upd }}$ ) between $0.05<E<0.4 \mathrm{~V}_{\mathrm{RHE}}$, adsorption of hydroxyl species $\left(\mathrm{OH}_{\mathrm{ad}}, \mathrm{H}_{2} \mathrm{O} \rightarrow \mathrm{OH}_{\mathrm{ad}}+\mathrm{H}^{+}+\mathrm{e}^{-}\right)$above 0.65 $\mathrm{V}_{\mathrm{RHE}}$, and the oxidation and reduction of $\mathrm{Pd} / \mathrm{PdO}$ over 1.05 $\mathrm{V}_{\mathrm{RHE}}$ and between $0.7>E>0.4 \mathrm{~V}_{\mathrm{RHE}}$, respectively. The voltammogram of $1 \% \mathrm{Pd}_{\mathrm{np}} / \mathrm{C}$ was entirely consistent with the literature for supported $\mathrm{Pd}$ catalysts possessing the described redox features of potential-dependent adsorbing species and $\mathrm{Pd}$ oxidation and reduction. The adsorption of hydrogen at $\mathrm{H}_{\text {UPD }}$ could drive the formation of Pd-hydrides in both the electrochemical and heterogeneous reactions, which has recently been observed spectroscopically during operando XAS measurements of $\mathrm{Pd}$ and AuPd catalysts during $\mathrm{H}_{2} \mathrm{O}_{2}$ synthesis. ${ }^{55}$ It has been suggested that these hydride phases can contribute toward $\mathrm{H}_{2} \mathrm{O}_{2}$ degradation, and it is known that extended $\mathrm{Pd}$ facets can facilitate $\mathrm{O}=\mathrm{O}$ bond cleavage, leading eventually to water formation. ${ }^{56,57}$ In contrast, the $\mathrm{PdCl}_{x} / \mathrm{C}$ with atomic dispersion showed no redox features consistent with the bulk reduction of $\mathrm{PdO}$ on the cathodic sweep despite being previously exposed to potentials of $1.5 \mathrm{~V}_{\mathrm{RHE}}$ during the anodic sweep, confirming the significantly different nanostructure of this catalyst. In addition, no associated charge in the hydrogen underpotential deposition region was observed, suggesting a general lack of $\mathrm{H}$-underpotential adsorption sites. The electrochemical features were maintained even after 1000 voltammetry cycles between 0.05 and $0.8 \mathrm{~V}_{\mathrm{RHE}}$, supporting the high stability in the potential window encompassing the ORR onset, and the dispersed $\mathrm{Pd}-\mathrm{Cl}$ species were not only resistant to sintering but also to bulk oxidation and reduction (Figure S4).

The nature of electrocatalytic testing allows the same catalyst to be tested separately for both half-reactions involved in the synthesis of $\mathrm{H}_{2} \mathrm{O}_{2}$ in heterogeneous systems, the $2 \mathrm{e}^{-}$ oxygen reduction and hydrogen oxidation reactions (ORR and $\mathrm{HOR}$, respectively). The bifunctionality of $\mathrm{PdCl}_{x} / \mathrm{C}$ is demonstrated by the potentiodynamic oxidation of molecular hydrogen (HOR). Figure $3 \mathrm{~b}$ shows the cyclic voltammograms at different rotation speeds in hydrogen-saturated $\mathrm{HClO}_{4}$ starting from $0.78 \mathrm{~V}_{\mathrm{RHE}}$ sweeping negatively to the potential limit of $-0.02 \mathrm{~V}_{\mathrm{RHE}}$ at which point the sweep was reversed. Hydrogen gas was introduced continuously during the measurements to maintain a saturated solution. The low amount of the supported catalyst leads to lower diffusionlimiting currents than theoretically expected as the total number of $\mathrm{Pd}$ atoms is too few to concede full overlap between adjacent diffusion zones. This behavior was also observed during the diffusion-limited ORR in acidic media for Ptloadings below $0.042 \mathrm{mg}_{\mathrm{Pt}} \mathrm{cm}_{\text {geo }}{ }^{-2} .{ }^{58}$ We clearly demonstrate that $\mathrm{PdCl}_{x} / \mathrm{C}$ is active toward the electrocatalytic hydrogen oxidation and that both redox reactions-HOR and ORRcan be evaluated separately with the possibility to use these descriptors to predict direct $\mathrm{H}_{2} \mathrm{O}_{2}$ synthesis activity in heterogeneous systems.

Figure 3c displays a characteristic set of current-voltage polarization curves for the oxygen reduction reaction on $\mathrm{PdCl}_{x} / \mathrm{C}, 1 \% \mathrm{Pd}_{\mathrm{np}} / \mathrm{C}$, and aqua regia-treated bare carbon as a reference in $0.1 \mathrm{M} \mathrm{HClO}_{4}$. For the standard nanoparticle containing $1 \% \mathrm{Pd}_{\mathrm{np}} / \mathrm{C}$, well-defined diffusion-limiting currents for the $4 \mathrm{e}^{-}$transfer reaction of $\mathrm{O}_{2}$ to $\mathrm{H}_{2} \mathrm{O}$ were observed from 0.35 to $0.7 \mathrm{~V}_{\mathrm{RHE}}$, followed by a mixed kinetic-diffusioncontrolled region between 0.8 and $1.0 \mathrm{~V}_{\mathrm{RHE}}$. The selectivity (Figure 3d) toward $\mathrm{H}_{2} \mathrm{O}_{2}$ measured by the ring current over the potential range from 1 to $0.1 \mathrm{~V}_{\mathrm{RHE}}$ was below $5 \%$ across the whole potential range. The onset potential for oxygen reduction was significantly different $\left(0.9 \mathrm{~V}_{\mathrm{RHE}}\right)$ compared to $\mathrm{PdCl}_{x} / \mathrm{C}\left(0.6 \mathrm{~V}_{\mathrm{RHE}}\right)$, showing that the nanostructure remains considerably different in the electrolyte solution. In contrast, the atomically dispersed $\mathrm{PdCl}_{x} / \mathrm{C}$ achieves a $\mathrm{H}_{2} \mathrm{O}_{2}$ selectivity of above $90 \%$ with a mass-normalized activity of $72.8 \mathrm{~A} \mathrm{~g}_{\mathrm{Pd}}{ }^{-1}$, which is among the best known oxygen-to-hydrogen peroxide reduction catalysts reported to date in acidic media without the need for alloying or surface blocking and also among the most selective Pd catalysts reported. ${ }^{27,41}$ A comparison with the state-of-the-art literature is included in Figure S5. The aqua regia-treated carbon as a reference showed similar $\mathrm{H}_{2} \mathrm{O}_{2}$ selectivity over the tested potential range but significantly 

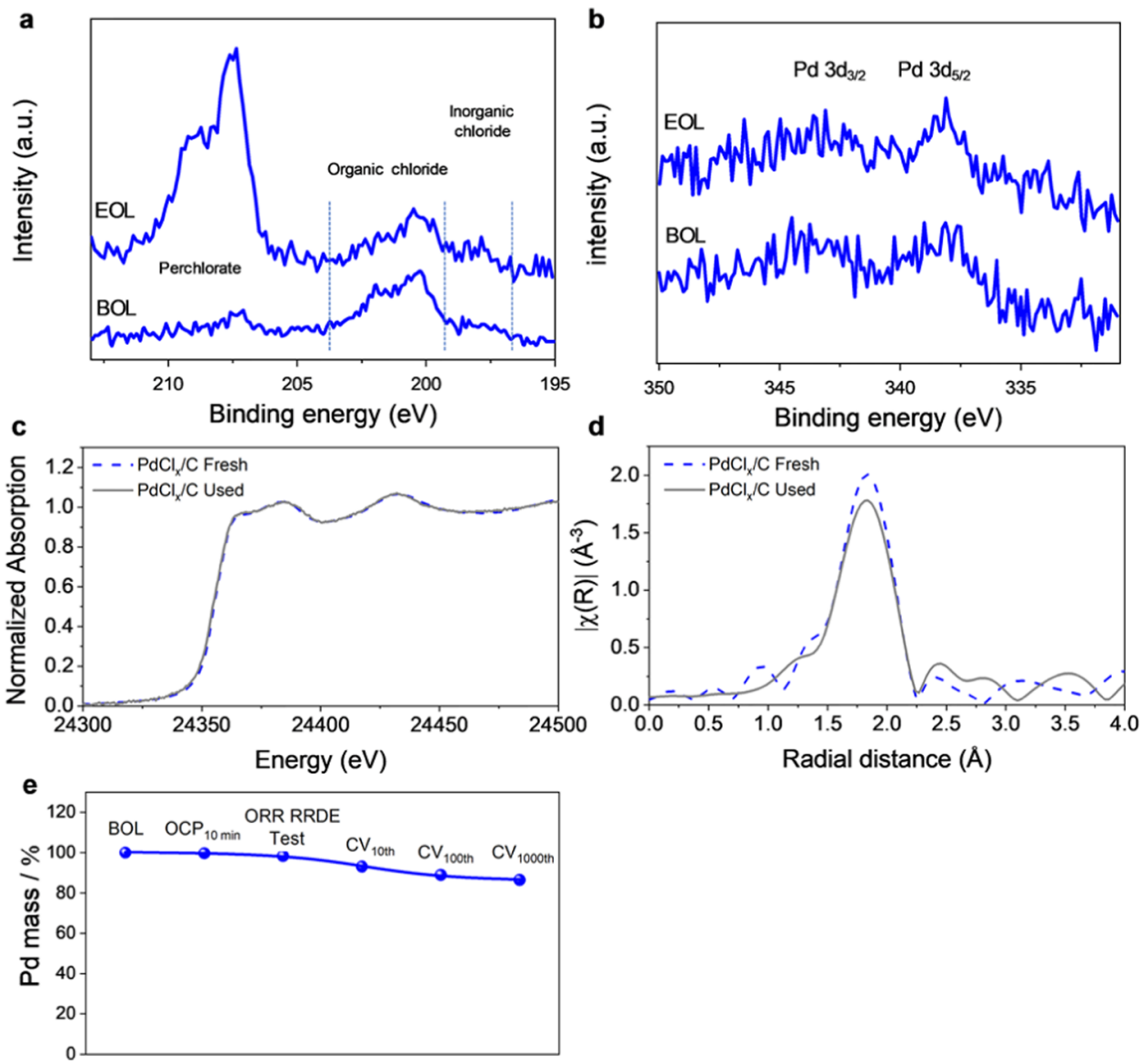

Figure 4. (a, b) Pd 3d and $\mathrm{Cl} 2 \mathrm{p}$ XPS characterization of fresh $\mathrm{PdCl}_{x} / \mathrm{C}(\mathrm{BOL})$ and after 1000 potential cycles between 0.05 and $0.8 \mathrm{~V}_{\mathrm{RHE}}$ at $1 \mathrm{~V}$ $\mathrm{s}^{-1}$ (EOL). (c, d) Pd K-edge X-ray absorption spectra and $k^{3}$-weighted Fourier transform (FT) magnitude of the as-prepared $\mathrm{PdCl} \mathrm{C}_{x} / \mathrm{C}$ before and after the direct $\mathrm{H}_{2} \mathrm{O}_{2}$ synthesis reaction. (e) Pd mass loss in a three-compartment cell in $\mathrm{HClO}_{4}$ monitored via ICP-MS after holding the working electrode at open circuit potential (OCP), after activity/selectivity measurements (cf. Figure 3 ) and after different numbers of degradation cycles between 0.05 and $0.8 \mathrm{~V}_{\mathrm{RHE}}$ at $1 \mathrm{~V} \mathrm{~s}^{-1}$.

higher overpotentials and a low activity toward the twoelectron oxygen reduction reaction. The results show that isolated cationic $\mathrm{PdCl}_{x}$ sites can make $\mathrm{H}_{2} \mathrm{O}_{2}$ with high selectivity and have little activity toward $\mathrm{H}_{2} \mathrm{O}_{2}$ degradation in the electrochemical ORR, showing distinct behavior compared to $\mathrm{Pd}$ nanoparticles that catalyze the four-electron reduction to $\mathrm{H}_{2} \mathrm{O}$ with near-complete selectivity. These results highlight the need to isolate $\mathrm{Pd}$ sites to produce selective catalysts for $\mathrm{H}_{2} \mathrm{O}_{2}$ synthesis.

Ex situ pre- (beginning-of-life; BOL) and post-catalytic (end-of-life, EOL) Pd and Cl XPS measurements of the electrode containing the $\mathrm{PdCl}_{x} / \mathrm{C}$ catalyst after electrochemical cycling above and below the ORR onset confirm the retention of $\mathrm{Cl}$ speciation. Binding energies associated with inorganic and organic chlorine after cycling support the high stability of these species (Figure 4a). Higher binding energy $\mathrm{Cl}$ speciation was present in the used sample associated with $\mathrm{ClO}_{4}{ }^{-}$retained on the catalyst surface from the electrolyte. No metallic $\mathrm{Pd}$ speciation was detected, suggesting that the high-surfaceenergy single atoms are not being reduced in the course of the reaction. Additionally, electrolyte aliquots were taken during an extended degradation protocol consisting of 1000 cycles between 0.05 and $0.8 \mathrm{~V}$ (above and below the ORR onset) and analyzed via inductively coupled plasma mass spectrometry (ICP-MS), as shown in Figure 4e. After 10 cycles, the catalyst stabilizes and only minimal Pd loss was observed subsequently. After 1000 degradation cycles, more than 83 atom \% of $\mathrm{Pd}$ was maintained in the catalyst and most $\mathrm{Pd}$ dissolves in the first 10 cycles until the surface stabilizes, which is commonly observed for noble and non-noble electrocatalysts.

In the direct reaction between $\mathrm{H}_{2}$ and $\mathrm{O}_{2}$ to form $\mathrm{H}_{2} \mathrm{O}_{2}$, molecular $\mathrm{H}_{2}$ must be cleaved-Pd surfaces or ensembles are capable of cleaving $\mathrm{H}_{2}$ with high rates. Alone, however, they are likely to result in significant $\mathrm{H}_{2} \mathrm{O}$ formation without the addition of a second metal or additives. Indeed, under our $\mathrm{H}_{2} \mathrm{O}_{2}$ direct synthesis conditions in the absence of acid and halide additives, the $1 \% \mathrm{Pd}_{\mathrm{np}} / \mathrm{C}$ catalyst containing $2-5 \mathrm{~nm} \mathrm{Pd}$ nanoparticles prepared by sol immobilization showed high productivity rates for $\mathrm{H}_{2} \mathrm{O}_{2}$ synthesis and also high rates of $\mathrm{H}_{2} \mathrm{O}_{2}$ overhydrogenation and degradation, consistent with the reported ability of the $\mathrm{Pd}$ particles to catalyze $\mathrm{O}=\mathrm{O}$ bond cleavage and water formation through overhydrogenation (Table 1). ${ }^{52}$

Having shown that the $\mathrm{PdCl}_{x} / \mathrm{C}$ catalyst is active for both the HOR and ORR electrochemically and selective towards $\mathrm{H}_{2} \mathrm{O}_{2}$, the isolated Pd sites may favor only end-on binding of molecular oxygen, which has been postulated to be the reason for high selectivity in single-site $\mathrm{Pt}$ catalysts for the twoelectron ORR, leading to increased $\mathrm{H}_{2} \mathrm{O}_{2}$ formation. ${ }^{31}$ Testing of the isolated site $\mathrm{Pd}$ catalyst in the autoclave system in the presence of $\mathrm{H}_{2}$ and $\mathrm{O}_{2}$ showed that the catalyst was capable of 
Table 1. Direct Synthesis and $\mathrm{H}_{2} \mathrm{O}_{2}$ Degradation Productivity of Catalysts Containing Metallic Pd Nanoparticles and Isolated $\mathrm{PdCl}_{x}$ Species

\begin{tabular}{|c|c|c|}
\hline catalyst & $\begin{array}{c}\mathrm{H}_{2} \mathrm{O}_{2} \text { productivity }^{a} \\
\left(\mathrm{~mol} \mathrm{~kg}^{-1} \mathrm{~h}^{-1}\right)\end{array}$ & $\begin{array}{c}\mathrm{H}_{2} \mathrm{O}_{2} \text { degradation rate } \\
(\text { mol kg } \\
\left.\mathrm{h}^{-1}\right)^{b} \\
\text { during the test })\end{array}$ \\
\hline $\begin{array}{l}\text { aqua regia- } \\
\text { treated carbon }\end{array}$ & 0 & $45(2 \%)$ \\
\hline $\begin{array}{c}1 \% \mathrm{PdCl}_{x} / \mathrm{C}- \\
\text { aqua regia }\end{array}$ & 30 & $52(3 \%)$ \\
\hline $\begin{array}{r}1 \% \mathrm{Pd}_{\mathrm{np}} / \mathrm{C} \text {-sol } \\
\text { immobilization }\end{array}$ & 120 & $360(20 \%)$ \\
\hline \multicolumn{3}{|c|}{$\begin{array}{l}{ }^{a}{ }_{2}{ }^{\circ} \mathrm{C}, 10 \mathrm{mg} \text { of catalyst, } 29 \mathrm{bar} 5 \% \mathrm{H}_{2} / \mathrm{CO}_{2}, 11 \mathrm{bar} 25 \% \mathrm{O}_{2} / \mathrm{CO}_{2}, 8.5 \\
\mathrm{~g} \text { of solvent }\left(5.6 \mathrm{~g} \text { of } \mathrm{CH}_{3} \mathrm{OH}+2.9 \mathrm{~g} \text { of } \mathrm{H}_{2} \mathrm{O}\right), 1200 \mathrm{rpm}, 30 \mathrm{~min} .{ }_{2} \\
{ }^{\circ} \mathrm{C}, 10 \mathrm{mg} \text { of catalyst, } 29 \text { bar } 5 \% \mathrm{H}_{2} / \mathrm{CO}_{2}, 8.5 \mathrm{~g} \text { of solvent }(5.6 \mathrm{~g} \text { of } \\
\left.\mathrm{CH}_{3} \mathrm{OH}+2.22 \mathrm{~g} \text { of } \mathrm{H}_{2} \mathrm{O}+0.68 \mathrm{~g} \text { of } 50 \% \mathrm{H}_{2} \mathrm{O}_{2}(10 \mathrm{mmol})\right), 1200 \\
\mathrm{rpm}, 30 \mathrm{~min} .\end{array}$} \\
\hline
\end{tabular}

synthesizing $\mathrm{H}_{2} \mathrm{O}_{2}$ at appreciable rates $\left(30 \mathrm{~mol} \mathrm{~kg}^{-1} \mathrm{~h}^{-1}\right)$ when compared to the nanoparticle catalyst. XAS and EXAFS analyses (Figure $4 \mathrm{c}, \mathrm{d}$ ) of the used $\mathrm{PdCl}_{x} / \mathrm{C}$ catalyst show minimal changes in the structure of the catalyst. The edge position remained constant, indicating that the palladium remained in a predominantly cationic state, suggesting that the $\mathrm{H}_{2}+\mathrm{O}_{2}$ atmosphere did not reduce the Pd species or induce sintering to nanoparticles. A significant $\mathrm{Pd}-\mathrm{Cl}$ scattering intensity remained in the EXAFS analysis after the autoclave test $(\mathrm{Pd}-\mathrm{Cl}$ coordination number $3.85 \pm 0.5)$.

The activity of the catalyst material toward $\mathrm{H}_{2} \mathrm{O}_{2}$ degradation under a pressure of $\mathrm{H}_{2}$ and in the presence of 4 wt $\% \mathrm{H}_{2} \mathrm{O}_{2}$ was significantly lower than that of the nanoparticle containing catalyst and within the error of the activity of the aqua regia-treated carbon alone. The testing of monometallic Pd catalysts is often carried out in the presence of strong mineral acids and halides to suppress the subsequent decomposition and hydrogenation of $\mathrm{H}_{2} \mathrm{O}_{2}$, so it cannot be used as a good comparison for intrinsic selectivity with our experimental setup. A comparison of the activity of the atomically dispersed $\mathrm{Pd} / \mathrm{C}$ with other catalysts able to achieve more than $95 \%$ selectivity with respect to $\mathrm{H}_{2}$ under the same reaction conditions is shown in Table S2, demonstrating that the catalyst has comparative performance per mole of precious metal with other state-of-the-art materials.

These observations suggest that the same active species could be responsible for the activity and high selectivity in the electrochemical ORR and the direct synthesis of $\mathrm{H}_{2} \mathrm{O}_{2}$ from $\mathrm{H}_{2}$ and $\mathrm{O}_{2}$-in this case, highly dispersed, strongly anchored $\mathrm{PdCl}_{x}$ species. The lower observed activity per Pd atom in this system compared to that of other bimetallic formulations where extended Pd facets are broken, such as the well-studied AuPd systems, could arise from the lack of electronic promotion from alloying second metal components or the high stability of the ligand environment surrounding the isolated Pd centers. This provides a route for future catalyst design through ligand optimization of the isolated $\mathrm{Pd}$ centers for both the electrochemical ORR and direct $\mathrm{H}_{2} \mathrm{O}_{2}$ synthesis. ${ }^{59,60}$

Considering the commonalities observed between the direct synthesis and electrochemical ORR, it could be unlikely that a purely Langmuir-type mechanism is in operation in both reactions as there is an absence of metallic $\mathrm{Pd}$ facets needed to support large surface coverages of $\mathrm{O}_{2} / \mathrm{OH} / \mathrm{OOH} / \mathrm{H}$ species. Additionally, there is no evidence of evolution of isolated $\mathrm{PdCl}_{x}$ into nanoparticles, which would lead to low selectivity as was observed using the metallic Pd nanoparticle catalyst. The requirement to activate $\mathrm{H}_{2}$ is absent in the electrochemical ORR as the $\mathrm{H}^{+} / \mathrm{e}^{-}$are supplied to the Pd-bound oxygenate species by the electrolyte and electrode, respectively. The observation of similar high selectivity in both systems could support the proposal of Flaherty et al. that the direct synthesis mechanism in the heterogeneous catalyst systems does in fact proceed through an electrochemical-type mechanism on the nanoparticle surface with electron conduction through the nanoparticles and protons shuttled through the protic solvent. $^{25}$ These observations are supported by the commonality observed between the performance of the same catalyst in the electrochemical and direct synthesis systems where catalyst evolution and subsequent reactions are minimal. Considering the proposal of Flaherty et al. based on nanoparticle catalysts, electron transport is needed between the site of HOR and ORR, in a nanoparticle, the metallic conductivity could be responsible for this connection. In a system where only isolated $\mathrm{Pd}$ sites are observed, it is possible to consider two mechanisms; first, a mononuclear mechanism where $\mathrm{O}_{2}$ and $\mathrm{H}_{2}$ activation occur on the same Pd center; however, we see minimal change in the $\mathrm{Pd}-\mathrm{Cl}$ coordination or oxidation state of $\mathrm{Pd}$. A second possibility is a cooperative mechanism where HOR and ORR occur on different Pd sites connected through the conductive support material-as we show that isolated Pd sites are active for both half-reactions in isolation. This would be similar in nature to the two isolated half-reactions occurring at different sites on the metal nanoparticle as proposed by Flaherty et al. ${ }^{25}$ This mechanism-akin to a fuel cell containing anodic and cathodic Pd sites connected electronically-could also explain the observation of limited activity for the previously reported highly dispersed $\mathrm{Pd}$ on nonconductive hydroxyapatite, where small metallic Pd clusters were required for activity. ${ }^{53}$

\section{CONCLUSIONS}

Overall, our findings show that that isolated cationic Pd species are highly selective toward the two-electron oxygen reduction reaction and show high mass activities. The synthesized singleatom species are stable during electrochemical cycling, thermal treatment, and under reaction conditions for both electrochemical and heterogeneous $\mathrm{H}_{2} \mathrm{O}_{2}$ production. Our results suggest that the electrochemical half-cell reactions can be used as guidelines for the development of selective $\mathrm{H}_{2} \mathrm{O}_{2}$ catalysts for heterogeneous catalysis.

\section{METHODS}

Catalyst Preparation. For the synthesis of 1 wt $\% \mathrm{PdCl}_{x} /$ $\mathrm{C}$, activated carbon (Norit ROX 0.8) was initially ground to obtain a 100-140 mesh powder. The palladium precursor, $\mathrm{PdCl}_{2}$ (Sigma-Aldrich, 99\%), was dissolved in $5.4 \mathrm{~mL}$ of aqua regia (3 parts by volume $\mathrm{HCl}$ (Fisher, 32 wt \%):1 part by volume $\mathrm{HNO}_{3}$ (Fisher, 70 wt \%)). The palladium precursor solution was then added dropwise with stirring to the activated carbon. Stirring was continued at ambient temperature until $\mathrm{NO}_{x}$ production had subsided. The product was then dried for $16 \mathrm{~h}$ at $140{ }^{\circ} \mathrm{C}$ under an inert flow of nitrogen. An analogous method was used in the absence of Pd to generate the aqua regia carbon for control experiments.

For the synthesis of $1 \mathrm{wt} \% \mathrm{Pd}_{\mathrm{np}} / \mathrm{C}$, an aqueous solution of $\mathrm{PdCl}_{2}\left(6 \mathrm{mg} \mathrm{mL}^{-1}\right)$ was prepared. Poly(vinyl alcohol) (PVA) ( 1 wt $\%$ aqueous solution, Aldrich, molecular weight $(\mathrm{MW})=$ 
$10000,80 \%$ hydrolyzed) and an aqueous solution of $\mathrm{NaBH}_{4}$ $(0.1 \mathrm{M})$ were also prepared. To $800 \mathrm{~mL}$ of water containing the appropriate amount of aqueous $\mathrm{PdCl}_{2}$, the required amount of the PVA solution ( 1 wt \%) was added (PVA/ $(\mathrm{Pd})(\mathrm{w} / \mathrm{w})=1.2)$; a freshly prepared solution of $\mathrm{NaBH}_{4}(0.1$ $\left.\mathrm{M}, \mathrm{NaBH}_{4} /(\mathrm{Pd})(\mathrm{mol} / \mathrm{mol})=5\right)$ was then added to form a dark-brown sol. After $30 \mathrm{~min}$ of sol generation, the colloid was immobilized by adding activated carbon (acidified at $\mathrm{pH} 1$ by sulfuric acid) under vigorous stirring conditions. The amount of the support material required was calculated so as to have a total final metal loading of 1 wt $\%$. After $2 \mathrm{~h}$, the slurry was filtered and the catalyst was washed thoroughly with distilled water (neutral mother liquors) and dried at $120{ }^{\circ} \mathrm{C}$ for $16 \mathrm{~h}$.

Catalyst Characterization. Powder $X$-ray Diffraction ( $p$ $X R D$ ). Powder X-ray diffraction ( $\mathrm{p}$-XRD) patterns (Figure $1 \mathrm{~b}$ ) were acquired using a Bruker D8 ADVANCE A25-X1 powder diffractometer in the Bragg-Brentano geometry employing a Co $\mathrm{K}_{\alpha}$ radiation source operating at $35 \mathrm{kV}$ and $40 \mathrm{~mA}(\Delta 2 \theta=$ $0.009^{\circ}$, count time $=112.32 \mathrm{~s}$ per step). A LYNXEYE XE-T energy-dispersive one-dimensional (1D) detector was used. The reference diffraction peaks for $\mathrm{Pd}(111)$ (JCPDS no. 461043) and $\mathrm{PdO}(101)$ (JCPDS no. 41-1107) measured with $\mathrm{Cu}$ $\mathrm{K}_{\alpha}$ were converted to Co $\mathrm{K}_{\alpha}$ using the following relation: $2 \theta(\mathrm{Co})=114.59156 \operatorname{asin}(1.7891 / 1.5418 \sin (0.00872664 .2 \theta$ $(\mathrm{Cu})))$.

In situ p-XRD (Figure 1c) was carried out using an X'pert Pro XRD fitted with an Anton Paar XRK900 in situ cell (internal volume of $0.5 \mathrm{~L}$ ) with XRD patterns recorded at $2 \theta$ between 30 and $80^{\circ}$ employing a $\mathrm{Cu} \mathrm{K}_{\alpha}$ radiation source operating at $40 \mathrm{keV}$ and $40 \mathrm{~mA}$. A flow of $\mathrm{Ar}\left(15 \mathrm{~mL} \mathrm{~min}^{-1}\right)$ was passed through the sample bed while the cell was heated to $400{ }^{\circ} \mathrm{C}\left(5{ }^{\circ} \mathrm{C} \mathrm{min}^{-1}\right)$ and kept for $5 \mathrm{~min}$ at a selected temperature before the diffraction patterns were collected. The spectra were analyzed using X'Pert High Score Plus software.

$X$-ray Photoemission Spectroscopy (XPS). For fresh powder materials, X-ray photoemission spectroscopy (XPS) was performed by using a Thermo Scientific K-Alpha photoelectron spectrometer with monochromatic $\mathrm{Al} \mathrm{K}_{\alpha}$ radiation. The resulting spectra were processed in CasaXPS and calibrated against the $\mathrm{C} 1 \mathrm{~s}$ line at $284.7 \mathrm{eV}$.

For electrode materials, the surface composition of $\mathrm{PdCl}_{x} / \mathrm{C}$ prior to and after electrochemical stability testing was determined using a Quantera II (Physical Electronics, Chanhassen, $\mathrm{MN}$ ), applying a monochromatic $\mathrm{Al} \mathrm{K}_{\alpha} \mathrm{X}$-ray source $(1486.6 \mathrm{eV})$ operating at $15 \mathrm{kV}$ and $25 \mathrm{~W}$. The $\mathrm{C} 1 \mathrm{~s}$ signal was referenced to $284.8 \mathrm{eV}$.

X-ray Absorption Spectroscopy (XAS). X-ray absorption fine structure (XAFS) spectra for all of the $\mathrm{Pd} / \mathrm{C}$ samples at the $\mathrm{Pd} \mathrm{K}$ absorption edge were recorded in transmission mode at the B18 beamline of Diamond Light Source, Harwell, U.K. The measurements were performed using a QEXAFS setup with a fast-scanning $\mathrm{Si}(111)$ double crystal monochromator. Demeter software packages (Athena and Artemis) were used for XAFS data analysis of the $\mathrm{Pd} / \mathrm{C}$ absorption spectra in comparison to standards relative to a Pd foil. The XANES spectra at the $\mathrm{Cl}$ K-edge were recorded at the BM28 (XMaS) beamline at the European Synchrotron Radiation Facility (ESRF) in Grenoble (France). The spectra were acquired in fluorescence mode. The fluorescence signal was detected using a silicon drift diode detector. PyMca software, developed by the Software Group of the European Synchrotron Radiation Facility (ESRF), was used for the spectral analysis.
Electron Microscopy. Scanning transmission electron microscopy measurements were carried out on a JEM2200FS (JEOL) operating at $200 \mathrm{kV}$ and on a FEI TITAN aberration-corrected (CEOS) electron microscope operating at $300 \mathrm{kV}$ equipped with an HAADF detector (73-352 mrad).

Electrochemical Reactivity. A three-compartment, inhouse-prepared Teflon cell was used as an electrochemical cell. The electrochemistry measurements were performed at room temperature $\left(25^{\circ} \mathrm{C}\right)$. As a reference electrode, a saturated $\mathrm{Ag} /$ $\mathrm{AgCl}$ electrode (Metrohm) was used, and a graphite rod was used as a counter electrode. Both are placed in separate compartments of the electrochemical cell separated by a Nafion membrane. As a working electrode, a commercially available RRDE tip was used (AFE6R1PT, Pine Research Instrumentation), consisting of a glassy carbon disk (0.196 $\left.\mathrm{cm}^{2}\right)$ and a Pt ring $(1 \mathrm{~mm}$ thickness $)$ embedded in a Peek tip. A catalyst ink in ultrapure water $(18 \mathrm{M} \Omega$, total organic carbon (TOC) $<3 \mathrm{ppb}$, ELGA) was prepared and drop-cast onto the glassy carbon electrode. An electrode loading of $10 \mu \mathrm{g}_{\text {metal }}$ $\mathrm{cm}^{-2}$ was used for all RRDE measurements. As an electrolyte, $0.1 \mathrm{M} \mathrm{HClO}_{4}$ prepared from ultrapure water and concentrated suprapure acid (Suprapur, Merck) was used. The collection efficiency ( 0.22$)$ of the ring was determined experimentally by calibration of the one-electron redox couple ferrocyanide $\left(\left[\mathrm{Fe}(\mathrm{CN})_{6}\right]^{4-}\right) /$ ferricyanide $\left(\left[\mathrm{Fe}(\mathrm{CN})_{6}\right]^{3-}\right)$ at different rotation rates. During RRDE measurements, the ring potential was set to a constant potential of $1.28 \mathrm{~V}_{\mathrm{RHE}}$. For the determination of Pd leaching during cycling, aliquots were taken after different times and analyzed via ICP-MS. ICP-MS analysis was performed using a NexION 300X from PerkinElmer. The quantitative determination of the ${ }^{106} \mathrm{Pd}$ content was obtained by comparison to calibrated internal standard solutions of ${ }^{103} \mathrm{Rh}$. A four-point calibration was done before each measurement. For HOR measurement, a catalyst loading of $0.00198 \mathrm{mg}_{\mathrm{Pd}} \mathrm{cm}^{-2}$ and the same Teflon cell as for RRDE measurements were used.

$\mathrm{H}_{2} \mathrm{O}_{2}$ Synthesis and Degradation. Hydrogen peroxide synthesis and degradation activity were evaluated using a Parr Instruments stainless steel autoclave with a nominal volume of $100 \mathrm{~mL}$. To test each catalyst for $\mathrm{H}_{2} \mathrm{O}_{2}$ synthesis, the autoclave was charged with $0.01 \mathrm{~g}$ of catalyst and $8.5 \mathrm{~g}$ of solvent $(5.6 \mathrm{~g}$ of $\mathrm{MeOH}$ and $2.9 \mathrm{~g}$ of $\mathrm{H}_{2} \mathrm{O}$, both high-performance liquid chromatography (HPLC) grade). The charged autoclave was then purged three times with $5 \% \mathrm{H}_{2} / \mathrm{CO}_{2}$ (7 bar) before being filled with $5 \% \mathrm{H}_{2} / \mathrm{CO}_{2}$ to a pressure of 29 bar followed by the addition of $25 \% \mathrm{O}_{2} / \mathrm{CO}_{2}$ (11 bar). The temperature was then allowed to decrease to $2{ }^{\circ} \mathrm{C}$ followed by stirring (at $1200 \mathrm{rpm}$ ) of the reaction mixture for $30 \mathrm{~min}$. The $\mathrm{H}_{2} \mathrm{O}_{2}$ productivity was determined by titrating aliquots of the final solution with acidified $\mathrm{Ce}\left(\mathrm{SO}_{4}\right)_{2}(0.01 \mathrm{M})$ in the presence of two drops of ferroin indicator. $\mathrm{H}_{2} \mathrm{O}_{2}$ degradation experiments were carried out in a similar manner to the $\mathrm{H}_{2} \mathrm{O}_{2}$ synthesis experiments but in the absence of $25 \% \mathrm{O}_{2} / \mathrm{CO}_{2}$. Furthermore, $0.68 \mathrm{~g}$ of $\mathrm{H}_{2} \mathrm{O}$ from the $8.5 \mathrm{~g}$ of solvent was replaced by a $50 \mathrm{vol} \% \mathrm{H}_{2} \mathrm{O}_{2}$ solution to give a reaction solvent containing 4 wt $\% \mathrm{H}_{2} \mathrm{O}_{2}$. The standard reaction conditions adopted for $\mathrm{H}_{2} \mathrm{O}_{2}$ degradation are as follows: $0.01 \mathrm{~g}$ of catalyst, $8.5 \mathrm{~g}$ of solvent ( $5.6 \mathrm{~g}$ of $\mathrm{MeOH}, 2.22 \mathrm{~g}$ of $\mathrm{H}_{2} \mathrm{O}$, and $0.68 \mathrm{~g}$ of $\left.\mathrm{H}_{2} \mathrm{O}_{2}(50 \%)\right)$, 29 bar $5 \%$ $\mathrm{H}_{2} / \mathrm{CO}_{2}, 2^{\circ} \mathrm{C}, 1200 \mathrm{rpm}$, and $30 \mathrm{~min}$. 


\section{ASSOCIATED CONTENT}

\section{(s) Supporting Information}

The Supporting Information is available free of charge at https://pubs.acs.org/doi/10.1021/acscatal.0c01305.

Additional catalyst characterization (XPS and TEM), EXAFS fitting parameters, extended CV measurements, and comparisons with the heterogeneous and electrocatalysis literature (PDF)

\section{AUTHOR INFORMATION}

\section{Corresponding Author}

Simon J. Freakley - Department of Chemistry, University of Bath, Bath BA2 7AY, U.K.; $\odot$ orcid.org/0000-0002-63956646; Email: s.freakley@bath.ac.uk

\section{Authors}

Marc Ledendecker - Department of Interface Chemistry and Surface Engineering, Max-Planck-Institut für Eisenforschung GmbH, 40237 Düsseldorf, Germany; Department of Technical Chemistry, Technical University Darmstadt, 64287 Darmstadt,

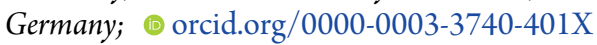

Enrico Pizzutilo - Department of Interface Chemistry and Surface Engineering, Max-Planck-Institut für Eisenforschung

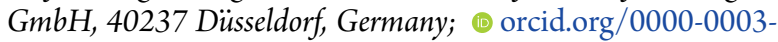
2733-7407

Grazia Malta - Cardiff Catalysis Institute, School of Chemistry, Cardiff University, Cardiff CF10 3AT, U.K.

Guilherme V. Fortunato - Department of Interface Chemistry and Surface Engineering, Max-Planck-Institut für Eisenforschung GmbH, 40237 Düsseldorf, Germany; Institute of Chemistry, Universidade Federal de Mato Grosso do Sul, Campo Grande, MS 79074-460, Brazil; 이잉.org/00000002-0768-4156

Karl J. J. Mayrhofer - Department of Interface Chemistry and Surface Engineering, Max-Planck-Institut für Eisenforschung GmbH, 40237 Düsseldorf, Germany; Helmholtz-Institute Erlangen-Nürnberg for Renewable Energy (IEK-11), Forschungszentrum Jülich, 91058 Erlangen, Germany; Department of Chemical and Biological Engineering, FriedrichAlexander-Universität Erlangen-Nürnberg, 91058 Erlangen, Germany

Graham J. Hutchings - Cardiff Catalysis Institute, School of Chemistry, Cardiff University, Cardiff CF10 3AT, U.K.; (1) orcid.org/0000-0001-8885-1560

Complete contact information is available at: https://pubs.acs.org/10.1021/acscatal.0c01305

\section{Notes}

The authors declare no competing financial interest.

\section{ACKNOWLEDGMENTS}

M.L. acknowledges the Federal Ministry of Education and Research (BMBF) in the framework of NanoMatFutur (SynKat, FK: 03XP0265) for financial support. K.J.J.M. acknowledges the Federal Ministry for Economic Affairs and Energy (BMWi) of Germany in the framework of PtTM@ HGS (project number 03ET6080A). E.P. acknowledges the financial support from the IMPRS-SurMat doctoral program. We thank Andrea Mingers for help with ICP-MS, Alexander Auer and Corentin Poidevin for fruitful discussions, and the MAXNET Energy and Cardiff University for the financial support of the project. S.J.F. acknowledges the University of
Bath for the award of a Prize Research Fellowship in Sustainable Technology. The authors thank the UK Catalysis Hub for allocating beamtime through the UK Catalysis Hub BAG for X-ray acquisition of the absorption spectroscopic data at the Diamond synchrotron facility (SP15151).

\section{REFERENCES}

(1) Jones, C. W. Applications of Hydrogen Peroxide and Derivatives; Royal Society of Chemistry: Cambridge, 1999; pp 207-230.

(2) Russo, V.; Tesser, R.; Santacesaria, E.; Di Serio, M. Chemical and Technical Aspects of Propene Oxide Production via Hydrogen Peroxide (HPPO Process). Ind. Eng. Chem. Res. 2013, 52, 11681178.

(3) Chen, Z.; Chen, S.; Siahrostami, S.; Chakthranont, P.; Hahn, C.; Nordlund, D.; Dimosthenis, S.; Nørskov, J. K.; Bao, Z.; Jaramillo, T. F. Development of a reactor with carbon catalysts for modular-scale, low-cost electrochemical generation of $\mathrm{H}_{2} \mathrm{O}_{2}$. React. Chem. Eng. 2017, 2, 239-245.

(4) Chen, Q. Development of an anthraquinone process for the production of hydrogen peroxide in a trickle bed reactor-From bench scale to industrial scale. Chem. Eng. Process. 2008, 47, 787-792.

(5) Campos-Martin, J. M.; Blanco-Brieva, G.; Fierro, J. L. G. Hydrogen peroxide synthesis: an outlook beyond the anthraquinone process. Angew. Chem., Int. Ed. 2006, 45, 6962-6984.

(6) García-Serna, J.; Moreno, T.; Biasi, P.; Cocero, M. J.; Mikkola, J. P.; Salmi, T. O. Engineering in direct synthesis of hydrogen peroxide: targets, reactors and guidelines for operational conditions. Green Chem. 2014, 16, 2320-2343.

(7) Henkel, H.; Weber, W. Manufacture of Hydrogen Peroxide. US1,108,752A, 1914.

(8) Samanta, C. Direct synthesis of hydrogen peroxide from hydrogen and oxygen: An overview of recent developments in the process. Appl. Catal., A 2008, 350, 133-149.

(9) Edwards, J. K.; Freakley, S. J.; Lewis, R. J.; Pritchard, J. C.; Hutchings, G. J. Advances in the direct synthesis of hydrogen peroxide from hydrogen and oxygen. Catal. Today 2015, 248, 3-9.

(10) Lewis, R. J.; Hutchings, G. J. Recent Advances in the Direct Synthesis of $\mathrm{H}_{2} \mathrm{O}_{2}$. ChemCatChem 2019, 11, 298-308.

(11) Seo, M. G.; Kim, H. J.; Han, S. S.; Lee, K. Y. Direct Synthesis of Hydrogen Peroxide from Hydrogen and Oxygen Using Tailored Pd Nanocatalysts: A Review of Recent Findings. Catal. Surv. Asia 2017, $21,1-12$.

(12) Yi, Y.; Wang, L.; Li, G.; Guo, H. A review on research progress in the direct synthesis of hydrogen peroxide from hydrogen and oxygen: noble-metal catalytic method, fuel-cell method and plasma method. Catal. Sci. Technol. 2016, 6, 1593-1610.

(13) Menegazzo, F.; Signoretto, M.; Ghedini, E.; Strukul, G. Looking for the "Dream Catalyst" for Hydrogen Peroxide Production from Hydrogen and Oxygen. Catalysts 2019, 9, No. 251.

(14) Ranganathan, S. S.; Sieber, V. Recent Advances in the Direct Synthesis of Hydrogen Peroxide Using Chemical Catalysis-A Review. Catalysts 2018, 8, No. 379.

(15) Choudhary, V. R.; Samanta, C.; Jana, P. Decomposition and/or hydrogenation of hydrogen peroxide over $\mathrm{Pd} / \mathrm{Al}_{2} \mathrm{O}_{3}$ catalyst in aqueous medium: Factors affecting the rate of $\mathrm{H}_{2} \mathrm{O}_{2}$ destruction in presence of hydrogen. Appl. Catal., A 2007, 332, 70-78.

(16) Choudhary, V. R.; Ingole, Y. V.; Samanta, C.; Jana, P. Direct oxidation of hydrogen to hydrogen peroxide over $\mathrm{Pd}$ (or $\mathrm{PdO}) / \mathrm{Al}_{2} \mathrm{O}_{3}$ in aqueous reaction medium: influence of different acids and halide anions in reaction medium on formation and destruction of $\mathrm{H}_{2} \mathrm{O}_{2}$. Ind. Eng. Chem. Res. 2007, 46, 8566-8573.

(17) Centomo, P.; Meneghini, C.; Sterchele, S.; Trapananti, A.; Aquilanti, G.; Zecca, M. EXAFS in situ: The effect of bromide on Pd during the catalytic direct synthesis of hydrogen peroxide. Catal. Today 2015, 248, 138-141.

(18) Edwards, J. K.; Freakley, S. J.; Carley, A. F.; Kiely, C. J.; Hutchings, G. J. Strategies for Designing Supported Gold-Palladium 
Bimetallic Catalysts for the Direct Synthesis of Hydrogen Peroxide. Acc. Chem. Res. 2014, 47, 845-854.

(19) Edwards, J. K.; Hutchings, G. J. Palladium and gold-palladium catalysts for the direct synthesis of hydrogen peroxide. Angew. Chem., Int. Ed. 2008, 47, 9192-9198.

(20) Edwards, J. K.; Solsona, B.; Ntanjua, E. N.; Carley, A. F.; Herzing, A. A.; Kiely, C. J.; Hutchings, G. J. Switching off hydrogen peroxide hydrogenation in the direct synthesis process. Science 2009, 323, 1037-1041.

(21) Freakley, S. J.; He, Q.; Harrhy, J. H.; Lu, L.; Crole, D. A.; Morgan, D. J.; Ntainjua, E. N.; Edwards, J. K.; Carley, A. F.; Borisevich, A. Y.; Kiely, C. J.; Hutchings, G. J. Palladium-tin catalysts for the direct synthesis of $\mathrm{H}_{2} \mathrm{O}_{2}$ with high selectivity. Science 2016, $351,965-968$.

(22) Maity, S.; Eswaramoorthy, M. Ni-Pd bimetallic catalysts for the direct synthesis of $\mathrm{H}_{2} \mathrm{O}_{2}$ - unusual enhancement of Pd activity in the presence of Ni. J. Mater. Chem. A 2016, 4, 3233-3237.

(23) Wang, S.; Gao, K.; Li, W.; Zhang, J. Effect of Zn addition on the direct synthesis of hydrogen peroxide over supported palladium catalysts. Appl. Catal., A 2017, 531, 89-95.

(24) Wilson, N. M.; Schröder, J.; Priyadarshini, P.; Bregante, D. T.; Kunz, S.; Flaherty, D. W. Direct synthesis of $\mathrm{H}_{2} \mathrm{O}_{2}$ on $\mathrm{PdZn}$ nanoparticles: The impact of electronic modifications and heterogeneity of active sites. J. Catal. 2018, 368, 261-274.

(25) Wilson, N. M.; Flaherty, D. W. Mechanism for the Direct Synthesis of $\mathrm{H}_{2} \mathrm{O}_{2}$ on Pd Clusters: Heterolytic Reaction Pathways at the Liquid-Solid Interface. J. Am. Chem. Soc. 2016, 138, 574-586.

(26) Yang, S.; Verdaguer Casadevall, A.; Arnarson, L.; Silvioli, L.; Čolić, V.; Frydendal, R.; Rossmeisl, J.; Chorkendorff, I.; Stephens, I. E. L. Toward the Decentralized Electrochemical Production of $\mathrm{H}_{2} \mathrm{O}_{2}$ : A Focus on the Catalysis. ACS Catal. 2018, 8, 4064-4081.

(27) Jiang, Y.; Ni, P.; Chen, C.; Lu, Y.; Yang, P.; Kong, B.; Fisher, A.; Wang, $\mathrm{X}$. Selective Electrochemical $\mathrm{H}_{2} \mathrm{O}_{2}$ Production through Two Electron Oxygen Electrochemistry. Adv. Energy Mater. 2018, 8, No. 1801909.

(28) Fortunato, G. V.; Pizzutilo, E.; Mingers, A. M.; Kasian, O.; Cherevko, S.; Cardoso, E. S. F.; Mayrhofer, K. J. J.; Maia, G.; Ledendecker, M. Impact of Palladium Loading and Interparticle Distance on the Selectivity for the Oxygen Reduction Reaction toward Hydrogen Peroxide. J. Phys. Chem. C 2018, 122, 1587815885 .

(29) Wang, Y. L.; Gurses, S.; Felvey, N.; Boubnov, A.; Mao, S. S.; Kronawitter, C. X. In Situ Deposition of Pd during Oxygen Reduction Yields Highly Selective and Active Electrocatalysts for Direct $\mathrm{H}_{2} \mathrm{O}_{2}$ Production. ACS Catal. 2019, 9, 8453-8463.

(30) Čolić, V.; Yang, S.; Révay, Z.; Stephens, I. E. L.; Chorkendorff, I. Carbon catalysts for electrochemical hydrogen peroxide production in acidic media. Electrochim. Acta 2018, 272, 192-202.

(31) Katsounaros, I.; Schneider, W. B.; Meier, J. C.; Benedikt, U.; Biedermann, P. U.; Cuesta, A.; Auer, A. A.; Mayrhofer, K. J. J. The impact of spectator species on the interaction of $\mathrm{H}_{2} \mathrm{O}_{2}$ with platinum - implications for the oxygen reduction reaction pathways. Phys. Chem. Chem. Phys. 2013, 15, 8058-8068.

(32) Choi, C. H.; Kwon, H. C.; Yook, S.; Shin, H.; Kim, H.; Choi, M. Hydrogen Peroxide Synthesis via Enhanced Two-Electron Oxygen Reduction Pathway on Carbon-Coated Pt Surface. J. Phys. Chem. C 2014, 118, 30063-30070.

(33) Pizzutilo, E.; Freakley, S. J.; Cherevko, S.; Venkatesan, S.; Hutchings, G. J.; Liebscher, C. H.; Dehm, G.; Mayrhofer, K. J. J. Gold-Palladium Bimetallic Catalyst Stability: Consequences for Hydrogen Peroxide Selectivity. ACS Catal. 2017, 7, 5699-5705.

(34) Chen, D.; Li, J.; Cui, P.; Liu, H.; Yang, J. Gold-catalyzed formation of core-shell gold-palladium nanoparticles with palladium shells up to three atomic layers. J. Mater. Chem. A 2016, 4, 38133821.

(35) Pizzutilo, E.; Kasian, O.; Choi, C. H.; Cherevko, S.; Hutchings, G. J.; Mayrhofer, K. J. J.; Freakley, S. J. Electrocatalytic synthesis of hydrogen peroxide on Au-Pd nanoparticles: From fundamentals to continuous production. Chem. Phys. Lett. 2017, 683, 436-442.
(36) Siahrostami, S.; Verdaguer-Casadevall, A.; Karamad, M.; Deiana, D.; Malacrida, P.; Wickman, B.; Escudero-Escribano, M.; Paoli, E. A.; Frydendal, R.; Hansen, T. W.; Chorkendorff, I.; Stephens, I. E. L.; Rossmeisl, J. Enabling direct $\mathrm{H}_{2} \mathrm{O}_{2}$ production through rational electrocatalyst design. Nat. Mater. 2013, 12, 1137-1143.

(37) Verdaguer-Casadevall, A.; Deiana, D.; Karamad, M.; Siahrostami, S.; Malacrida, P.; Hansen, T. W.; Rossmeisl, J.; Chorkendorff, I.; Stephens, I. E. L. Trends in the electrochemical synthesis of $\mathrm{H}_{2} \mathrm{O}_{2}$ : enhancing activity and selectivity by electrocatalytic site engineering. Nano Lett. 2014, 14, 1603-1608.

(38) Tsionskii, V. M.; Kriksunov, L. B. Cathodic hydrogen evolution on mercury from aqueous solutions of dilute acids at temperatures higher than $100{ }^{\circ} \mathrm{C}$. J. Electroanal. Chem. Interfacial Electrochem. 1986, 204, 131-140.

(39) Yang, S.; Tak, Y. J.; Kim, J.; Soon, A.; Lee, H. Support Effects in Single-Atom Platinum Catalysts for Electrochemical Oxygen Reduction. ACS Catal. 2017, 7, 1301-1307.

(40) Yang, S.; Kim, J.; Tak, Y. J.; Soon, A.; Lee, H. Single-Atom Catalyst of Platinum Supported on Titanium Nitride for Selective Electrochemical Reactions. Angew. Chem., Int. Ed. 2016, 55, 20582062.

(41) Choi, C. H.; Kim, M.; Kwon, H. C.; Cho, S. J.; Yun, S.; Kim, H. T.; Mayrhofer, K. J. J.; Kim, H.; Choi, M. Tuning selectivity of electrochemical reactions by atomically dispersed platinum catalyst. Nat. Commun. 2016, 7, No. 10922.

(42) Yamanaka, I.; Ichihashi, R.; Iwasaki, T.; Nishimura, N.; Murayama, T.; Ueda, W.; Takenaka, S. Electrocatalysis of heat-treated cobalt-porphyrin/carbon for hydrogen peroxide formation. Electrochim. Acta 2013, 108, 321-329.

(43) Staszak-Jirkovský, J.; Ahlberg, E.; Panas, I.; Schiffrin, D. J. The bifurcation point of the oxygen reduction reaction on $\mathrm{Au}-\mathrm{Pd}$ nanoalloys. Faraday Discuss. 2016, 188, 257-278.

(44) Jirkovský, J. S.; Panas, I.; Romani, S.; Ahlberg, E.; Schiffrin, D. J. Potential-Dependent Structural Memory Effects in $\mathrm{Au}-\mathrm{Pd}$ Nanoalloys. J. Phys. Chem. Lett. 2012, 3, 315-321.

(45) Malta, G.; Kondrat, S. A.; Freakley, S. J.; Davies, C. J.; Lu, L.; Dawson, S.; Thetford, A.; Gibson, E. K.; Morgan, D. J.; Jones, W.; Wells, P. P.; Johnston, P.; Catlow, C. R. A.; Kiely, C. J.; Hutchings, G. J. Identification of single-site gold catalysis in acetylene hydrochlorination. Science 2017, 355, 1399-1403.

(46) Noack, K.; Zbinden, H.; Schlögl, R. Identification of the state of palladium in various hydrogenation catalysts by XPS. Catal. Lett. 1990, 4, 145-155.

(47) Fujikawa, T.; Tsuji, K.; Mizuguchi, H.; Godo, H.; Iedi, K.; Usui, $\mathrm{K}$. EXAFS characterization of bimetallic $\mathrm{Pt}-\mathrm{Pd} / \mathrm{SiO}_{2}-\mathrm{Al}_{2} \mathrm{O}_{3}$ catalysts for hydrogenation of aromatics in diesel fuel. Catal. Lett. 1999, 63, 27-33.

(48) Leri, A. C.; Marcus, M. A.; Myneni, S. C. B. Quantitative speciation of absolute organohalogen concentrations in environmental samples by X-ray absorption spectroscopy. Geochim. Cosmochim. Acta 2007, 71, 5834-5846.

(49) Lopes, C. W.; Cerrillo, J. L.; Palomares, A. E.; Rey, F.; Agostini, G. An in situ XAS study of the activation of precursor-dependent Pd nanoparticles. Phys. Chem. Chem. Phys. 2018, 20, 12700-12709.

(50) Liu, Y.; Zhou, Y.; Li, J.; Wang, Q.; Qin, Q.; Zhang, W.; Asakura, H.; Yan, N.; Wang, J. Direct aerobic oxidative homocoupling of benzene to biphenyl over functional porous organic polymer supported atomically dispersed palladium catalyst. Appl. Catal., B 2017, 209, 679-688.

(51) Pizzutilo, E.; Freakley, S. J.; Geiger, S.; Baldizzone, C.; Mingers, A.; Hutchings, G. J.; Mayrhofer, K. J. J.; Cherevko, S. Addressing stability challenges of using bimetallic electrocatalysts: the case of gold-palladium nanoalloys. Catal. Sci. Technol. 2017, 7, 1848-1856.

(52) Pritchard, J.; Kesavan, L.; Piccinini, M.; He, Q.; Tiruvalam, R.; Dimitratos, N.; Lopez-Sanchez, J. A.; Carley, A. F.; Edwards, J. K.; Kiely, C. J.; Hutchings, G. J. Direct Synthesis of Hydrogen Peroxide and Benzyl Alcohol Oxidation Using Au-Pd Catalysts Prepared by Sol Immobilization. Langmuir 2010, 26, 16568-16577. 
(53) Tian, P.; Ouyang, L.; Xu, X.; Ao, C.; Xu, X.; Si, R.; Shen, X.; Lin, M.; Xu, J.; Han, Y. F. The origin of palladium particle size effects in the direct synthesis of $\mathrm{H}_{2} \mathrm{O}_{2}$ : Is smaller better? J. Catal. 2017, 349, $30-40$.

(54) Vilé, G.; Albani, D.; Nachtegaal, M.; Chen, Z.; Dontsova, D.; Antonietti, M.; López, N.; Pérez-Ramírez, J. A stable single-site palladium catalyst for hydrogenations. Angew. Chem., Int. Ed. 2015, 54, 11265-11269.

(55) Łosiewicz, B.; Birry, L.; Lasia, A. Effect of adsorbed carbon monoxide on the kinetics of hydrogen electrosorption into palladium. J. Electroanal. Chem. 2007, 611, 26-34.

(56) Selinsek, M.; Deschner, B. J.; Doronkin, D. E.; Sheppard, T. L.; Grunwaldt, J. D.; Dittmeyer, R. Revealing the Structure and Mechanism of Palladium during Direct Synthesis of Hydrogen Peroxide in Continuous Flow Using Operando Spectroscopy. ACS Catal. 2018, 8, 2546-2557.

(57) Kanungo, S.; van Haandel, L.; Hensen, E. J. M.; Schouten, J. C.; Neira d'Angelo, M. F. Direct synthesis of hydrogen peroxide in AuPd coated micro channels: an in-situ XAS study. J. Catal. 2019, 370, 200-209.

(58) Mayrhofer, K. J. J.; Strmcnik, D.; Blizanac, B. B.; Stamenkovic, V.; Arenz, M.; Markovic, N. M. Measurement of oxygen reduction activities via the rotating disc electrode method: From Pt model surfaces to carbon-supported high surface area catalysts. Electrochim. Acta 2008, 53, 3181-3188.

(59) Strmcnik, D.; Uchimura, M.; Wang, C.; Subbaraman, R.; Danilovic, N.; van der Vliet, D.; Paulikas, A. P.; Stamenkovic, V. R.; Markovic, N. M. Improving the hydrogen oxidation reaction rate by promotion of hydroxyl adsorption. Nat. Chem. 2013, 5, 300-306.

(60) Wilson, N. M.; Priyadarshini, P.; Kunz, S.; Flaherty, D. W. Direct synthesis of $\mathrm{H}_{2} \mathrm{O}_{2}$ on $\mathrm{Pd}$ and $\mathrm{Au}_{\mathrm{x}} \mathrm{Pd}_{1}$ clusters: Understanding the effects of alloying Pd with Au. J. Catal. 2018, 357, 163-175. 